\title{
Evaluation of the impacts of climate change on disease vectors through ecological niche modelling
}

\author{
B.M. Carvalho ${ }^{1,2,3 *}$, E.F. Rangel ${ }^{2}$ and M.M. Vale ${ }^{1}$ \\ ${ }^{1}$ Laboratório de Vertebrados, Instituto de Biologia, Universidade Federal do \\ Rio de Janeiro, Rio de Janeiro, Brazil: ${ }^{2}$ Laboratório Interdisciplinar de \\ Vigilância Entomológica em Diptera e Hemiptera, Instituto Oswaldo Cruz, \\ Fundação Oswaldo Cruz, Rio de Janeiro, Brazil: ${ }^{3}$ Pós-Graduação em Ecologia \\ e Evolução, Universidade do Estado do Rio de Janeiro, Rio de Janeiro, Brazil
}

\begin{abstract}
Vector-borne diseases are exceptionally sensitive to climate change. Predicting vector occurrence in specific regions is a challenge that disease control programs must meet in order to plan and execute control interventions and climate change adaptation measures. Recently, an increasing number of scientific articles have applied ecological niche modelling (ENM) to study medically important insects and ticks. With a myriad of available methods, it is challenging to interpret their results. Here we review the future projections of disease vectors produced by ENM, and assess their trends and limitations. Tropical regions are currently occupied by many vector species; but future projections indicate poleward expansions of suitable climates for their occurrence and, therefore, entomological surveillance must be continuously done in areas projected to become suitable. The most commonly applied methods were the maximum entropy algorithm, generalized linear models, the genetic algorithm for rule set prediction, and discriminant analysis. Lack of consideration of the full-known current distribution of the target species on models with future projections has led to questionable predictions. We conclude that there is no ideal 'gold standard' method to model vector distributions; researchers are encouraged to test different methods for the same data. Such practice is becoming common in the field of ENM, but still lags behind in studies of disease vectors.
\end{abstract}

Keywords: vector-borne diseases, spatial distribution, ensemble modelling, Aedes, Anopheles, Lutzomyia, Phlebotomus, Culicoides, Triatoma, Ixodes

(Accepted 14 November 2016; First published online 15 December 2016)

\section{Introduction}

Climate change is happening more quickly and strongly than predicted, and the anthropic influence in this process is now clear (IPCC, 2014). Projections from several greenhouse gas emission scenarios agree on an increase of the mean earth surface temperature by the end of the 21st century, with continents

*Author for correspondence

Phone: +55212562 1375

E-mail: brunomc@ioc.fiocruz.br heating more than oceans and high latitude regions heating more than the tropics. Longer and more frequent heat waves will probably occur, as well as more intense precipitation events in several regions (IPCC, 2014). Increased floods, droughts, fires, heat waves and air pollutants will directly impact human health. Indirect impacts on human health will arise from ecological disturbances and social responses to disruptions to agriculture, and to water and food supplies. Vector-borne diseases will also increase, compounded by human migrations towards endemic areas (Woodward et al., 2014).

Vector-borne diseases are exceptionally sensitive to climate change because they emerge from complex transmission 
cycles involving several species of pathogens, vectors and hosts (Parham et al., 2015). Most disease vectors are arthropods, including insects and ticks. Climate change should, therefore, cause changes in disease distribution, density, seasonality and prevalence, and might prompt adaptation of vectors and hosts to new transmission cycles (Kovats et al., 2001; Brooks \& Hoberg, 2007; Rosenthal, 2009; Mills et al., 2010).

The ecology of arthropod vectors should be impacted by climate change at three levels of biological organization: (i) at the individual level - being ectothermic organisms, vectors' metabolism varies with daily fluctuations in temperature, which may affect physiological traits related to vector competence (Paaijmans et al., 2013) such as muscle activity (Harrison \& Roberts, 2000) and biting rates, although this latter influence is not entirely clear (Rogers \& Randolph, 2006; Ready, 2013); (ii) at the population level - changes in climate should influence abundance, density, seasonality, survival rates, generation time, fecundity and dispersion ability, allowing vectors to colonize new habitats more efficiently (Mills et al., 2010; Stange \& Ayres, 2010; Eisen et al., 2014); (iii) at the community level - parasite-vector interactions can be influenced by temperature (Hlavacova et al., 2013), and new species of vectors or hosts can adapt to existing transmission cycles (Kovats et al., 2001; Rosenthal, 2009; Parham et al., 2015).

Knowledge of vectors' spatial distributions is essential to assess transmission risks in different regions. Predicting vector occurrence in specific regions is a challenge that many disease control programs must meet in order to plan and execute control interventions and adaptation measures more efficiently. With the popularization of GIS (geographic information systems), increasing availability of species occurrence data, disease information and environmental variables, various methods of spatial analysis and mathematical modelling have become common in the scientific literature. The methods that correlate these available data in order to predict species' distributions are known as ecological niche models (ENMs) or species distribution models and have been widely used in studies of ecology, biogeography and conservation (Guisan \& Zimmermann, 2000; Guisan \& Thuiller, 2005; Elith \& Leathwick, 2009). Recently, an increasing number of scientific articles have applied these models to study distributions of many medically important insect and tick species.

Ecological niche models are perhaps the most used methods to link climatic and environmental conditions to the distribution of species. In an ENM, an algorithm takes as input occurrence records of the studied species and calculates their relation with environmental variables, producing a surface of environmental suitability or probability of occurrence (Guisan \& Zimmermann, 2000; Franklin, 2010; Peterson et al., 2011). There are two basic approaches to apply an ENM in studies of vector-borne diseases. The first considers the entire transmission cycle and their ecological relationships as a black box', and analyses the geographical distribution of the disease occurrence, as if it were a single species (e.g. Nieto et al., 2006; Yé et al., 2007; Williams et al., 2008; Arboleda et al., 2009). This approach indirectly groups all component species of the transmission cycle, as well as their environmental needs and ecological interactions, losing, therefore, important details of the transmission process. However, the occurrence of the disease is often the only information available, and this becomes the only modelling option. The second approach is to model each species from the transmission cycle individually, and evaluate areas of co-occurrence afterwards. This approach offers the opportunity to distinguish different reasons for the presence or absence of disease transmission in certain locations. For example, the disease may be absent due to the lack of the pathogen, an appropriate vector or a reservoir host (Peterson et al., 2011). Areas with the presence of only vectors and competent hosts may be treated as vulnerable - a particularly important situation nowadays, when species are artificially transported by humans and new diseases emerge in areas where they would not naturally occur (Komar, 2003; Ready, 2008, 2010; Daszak et al., 2013).

Comparative studies show that most of uncertainty in ENM comes from using different modelling algorithms (Buisson et al., 2009; Diniz-Filho et al., 2009; Elith \& Graham, 2009). With the wide variety of methods, it is an additional challenge to interpret and compare the results of studies on vector distributions, so that they can be effectively used in control programs. Here we review the future projections of disease vectors produced by ENMs, and assess trends and limitations of the methods applied.

\section{Methods}

We performed a systematic review of the literature using four online databases: (i) Web of Science (http://isiwebofknowledge.com); (ii) Scopus (http://www.hub.sciverse. com); (iii) Pubmed (http://www.ncbi.nlm.nih.gov/pubmed); and (iv) Scientific Electronic Library Online (SciELO) (http:// www.scielo.org). The Web of Science is the most comprehensive database of peer-reviewed articles published in English, as well as being the most used in systematic reviews (Falagas et al., 2008; Gavel \& Iselid, 2008). However, Scopus covers a larger number of journals that publish articles in languages other than English (Falagas et al., 2008; Gavel \& Iselid, 2008). PubMed is the most frequently consulted source for information in the biomedical field (Falagas et al., 2008). The SciELO database, although less comprehensive, includes many Latin American journals that are not included in the other consulted databases.

Searches were conducted in March 2015, through different combinations of the following key words: 'ecologic* niche model $^{* \prime}$ 'species distribution model ${ }^{* \prime}$, 'climat* model ${ }^{* \prime}$, 'vector', 'disease'. The initial results $(N=572)$ were limited to articles published until 2014 that applied ENMs to predict areas of occurrence or environmental suitability of arthropods vectors of diseases. Articles that used models to explain the relationship of the vectors with environmental variables, without predictive mapping, were excluded from the analysis. Studies with models based only on the occurrence of disease or risk maps generated without vector information were also discarded. After removing duplicates and refining selections, 146 articles were reviewed (Table S1).

The articles were described under the following categories: vector species and main associated disease; study area; types of biological data; types of environmental data; applied method; inclusion of future projections (Table S1). Studies including future projections were analysed in greater detail in relation to biological data (number of records, data source), environmental data (number of variables, approximate spatial resolution), methods (algorithm employed, use of ensemble models based on different algorithms) and future projections (years, general circulation model, climate change scenario) (Table S2). The main results of the future projections were summarized by vector group and further described. 


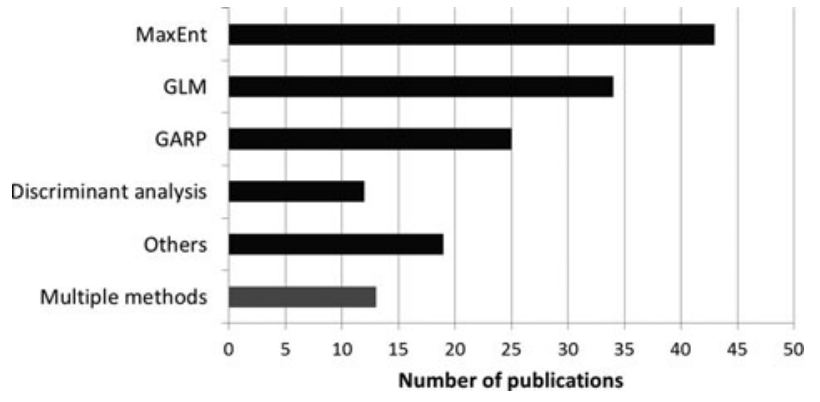

Fig. 1. Methods applied in the literature of ecological niche modelling of arthropod vectors of diseases.

\section{Results and discussion}

\section{Application of different modelling methods}

Seventeen different modelling methods were used to predict vector distributions. The most common was the maximum entropy algorithm (MaxEnt, 43 articles) (Phillips et al., 2006), followed by generalized linear models (GLM, 34) (Guisan et al., 2002), the genetic algorithm for rule set prediction (GARP, 25) (Stockwell, 1999), and discriminant analysis (12) (Rogers et al., 1996) (fig. 1, Table S1). Other methods were less frequently applied, such as CLIMEX (5) (Sutherst \& Maywald, 1985), ENFA (3) (Hirzel et al., 2002), BRT (2) (Elith et al., 2008), BIOCLIM (1) (Booth et al., 2014) and Random Forests (1) (Breiman, 2001) (fig. 1, Table S1). For comprehensive descriptions of ENM algorithms, see Franklin (2010) and Peterson et al. (2011).

The predictive performance of MaxEnt has exceeded other algorithms in several comparative studies (Elith et al., 2006; Foley et al., 2009, 2010; Larson et al., 2010; Arboleda et al., 2012). In addition, its popularity can probably be explained by the fact that it is implemented in free software with a userfriendly interface, good documentation and many options for parameterization. Generalized linear models were the secondmost frequent method because they offer more flexibility than machine learning algorithms (e.g. MaxEnt and GARP), thus improving model fit and ecological interpretations of parameters (Franklin, 2010). Also noteworthy is the use of CLIMEX, a mechanistic (process-based) algorithm. Mechanistic models are based on vector's biological processes, such as duration of life cycle, biting rates, dispersal ability, temperature limits for larvae development, etc. The inclusion of this type of data improves the biological meaning of models, but they require solid empirical knowledge about the vectors' physiology, which makes parameterization a challenge (Kearney \& Porter, 2009; Dormann et al., 2012; Fischer et al., 2014).

Models produced by different algorithms may have dissimilar, even contrasting outputs (Dormann et al., 2008; Diniz et al., 2009; Elith \& Graham, 2009; Li \& Wang, 2013). Independent evaluations have often been unable to identify a single recommended algorithm for all circumstances (Elith et al., 2006; Elith \& Graham, 2009; Li \& Wang, 2013; Qiao et al., 2015). An alternative to avoid the choice of a particular method is to test models produced by a set of algorithms (Qiao et al., 2015) and combine their results as an ensemble model (Araújo \& New, 2007; Marmion et al., 2009). With a set of models produced by a number of algorithms, uncertainty can be properly quantified, thus improving the study's result
(Pearson et al., 2006; Owens et al., 2013; Qiao et al., 2015). The use of multiple algorithms was present in over $70 \%$ of general ENM studies published recently (Guillera-Arroita et al., 2015), but it was under-represented in ENM of disease vectors for the same period (approximately 10\%). This represents a significant delay in disease vector studies in relation to what is currently being published.

A good example of the multiple algorithm approach was a comparison between models produced by BIOCLIM, DOMAIN (Carpenter et al., 1993), GARP, GLM (logistic regression) and MaxEnt to identify areas of high density of Aedes mosquitoes in Bermuda (Khatchikian et al., 2011). The results varied between the different algorithms, but since GLM and MaxEnt performed better, both were used to predict risk areas of mosquito infestations (Khatchikian et al., 2011). Another example was a study of the distribution patterns of natural breeding sites of $A$. aegypti in Colombia, where models produced by GARP had fewer omission errors than those produced by MaxEnt (Arboleda et al., 2012). Models produced by MaxEnt performed better in certain regions, although areas predicted as suitable by the two algorithms coincided closely. The two algorithms were combined into an ensemble model, where coincident areas were considered suitable with greater confidence. The combination of methods improved the detection of natural breeding sites, allowing the optimization of effort and financial investment in dengue control programs in the region (Arboleda et al., 2012).

\section{Future projections of vector distributions}

Over 700 vector species were studied in the 146 reviewed papers, including mostly mosquitoes (63 articles) and sand flies (29), followed by works on kissing bugs (18), biting midges (17), ticks (14), tsetse flies (3), fleas (1) and water bugs (1) (Table S1). The geographic extent of the reviewed studies varied from local to global (Table S1). The 31 studies with future ENM projections mostly point to expansions in response to climate change scenarios, accompanied by poleward shifts (table 1). This trend is being observed for several taxonomic groups, where long-term field studies demonstrate recent species' movements towards higher latitudes and higher altitudes in response to climate change (Hickling et al., 2006; Stange \& Ayres, 2010; Chen et al., 2011). There is, however, a noteworthy methodological issue in about half of the reviewed studies (table 1). When projecting into future scenarios, models should be trained with the full-known distribution of the species. If only a subset of the realized niche is used, future predictions may underestimate environmentally suitable areas and quantifications of range changes become questionable (Pearson \& Dawson, 2003; Guisan \& Thuiller, 2005; Araújo \& Peterson, 2012). An additional source of uncertainty in future forecasts is the extrapolation of models into climatic conditions that do not presently exist (Fitzpatrick \& Hargrove, 2009). Some ENM algorithms have standard ways of controlling extrapolation, such as MaxEnt, by limiting output values to the range of environmental variables under which the model was calibrated (Phillips et al., 2006). Alternatively, out-of-range values can be masked directly in model predictions (Owens et al., 2013; Carvalho et al., 2015).

\section{Aedes aegypti and Aedes albopictus (Diptera: Culicidae)}

The main vector of dengue, A. aegypti, is currently distributed throughout most tropical regions of the world. 
Table 1. Overview of the future projections of the distributions of arthropod vectors of diseases.

\begin{tabular}{|c|c|c|c|c|c|c|c|c|}
\hline Species & Main disease & Study area & $\begin{array}{l}\text { Full current } \\
\text { distribution } \\
\text { of species }\end{array}$ & Algorithm & $\begin{array}{l}\text { Year of } \\
\text { projections }\end{array}$ & $\begin{array}{l}\text { Difference of pro- } \\
\text { jected area }\end{array}$ & $\begin{array}{l}\text { General range shift } \\
\text { directions }\end{array}$ & Reference \\
\hline \multicolumn{9}{|l|}{ Diptera: Culicidae } \\
\hline Aedes aegypti & Dengue & Australia & No & GARP & 2030,2050 & Expansion & Central, south & Beebe et al. (2009) \\
\hline Aedes aegypti & Dengue & Global & Yes & Alpha-shapes & 2010-2040 & $\begin{array}{l}\text { Expansion and } \\
\text { contraction }\end{array}$ & Several directions & Capinha et al. (2014) \\
\hline Aedes aegypti & Dengue & Brazil & No & MaxEnt & 2050 & Contraction & South & $\begin{array}{l}\text { Cardoso-Leite } \text { et al. } \\
\text { (2014) }\end{array}$ \\
\hline Aedes aegypti & Dengue & Global & Yes & CLIMEX & 2030,2070 & $\begin{array}{l}\text { Contraction, discrete } \\
\text { expansion }\end{array}$ & Several directions & $\begin{array}{l}\text { Khormi and Kumar } \\
\text { (2014) }\end{array}$ \\
\hline Aedes albopictus & Arboviruses & Trentino, Italia & No & GLM (logistic) & 2050 & Expansion & East, west & Roiz et al. (2011) \\
\hline Aedes albopictus & Arboviruses & Europe & Yes & MaxEnt & $\begin{array}{l}2040,2070 \\
2100\end{array}$ & Expansion & North, east, west & Fischer et al. (2011c) \\
\hline Aedes albopictus & Arboviruses & Australia, global & Yes & $\begin{array}{l}\text { MaxEnt, } \\
\text { CLIMEX }\end{array}$ & 2030,2050 & Discrete expansion & Central & Hill et al. (2014) \\
\hline Aedes stictus & Arboviruses & Sweden & No & Other & $\begin{array}{l}2020,2050, \\
2080\end{array}$ & Expansion & North & $\begin{array}{l}\text { Schäfer and Lundström } \\
\text { (2009) }\end{array}$ \\
\hline $\begin{array}{l}\text { Anopheles } \\
\quad \text { arabiensis }\end{array}$ & Malaria & $\begin{array}{l}\text { Sudan and North } \\
\text { of Egypt }\end{array}$ & No & MaxEnt & 2050 & Expansion & Not given & Fuller et al. (2012) \\
\hline $\begin{array}{l}\text { Anopheles } \\
\text { arabiensis }\end{array}$ & Malaria & Africa & Yes & LOBAG-OC & 2050 & Contraction & East, southeast & Drake and Beier (2014) \\
\hline $\begin{array}{l}\text { Anopheles gambiae } \\
\text { and Anopheles } \\
\text { arabiensis }\end{array}$ & Malaria & Africa & Yes & CLIMEX & Not given & Expansion & South, east & Tonnang et al. (2010) \\
\hline $\begin{array}{l}\text { Anopheles gambiae } \\
\text { and Anopheles } \\
\text { arabiensis }\end{array}$ & Malaria & Africa & Yes & GARP & 2055 & Expansion & South, east & Peterson (2009) \\
\hline $\begin{array}{l}\text { Anopheles gambiae } \\
\text { and Anopheles } \\
\text { arabiensis }\end{array}$ & Malaria & Africa & Yes & CLIMEX & Not given & Expansion & South, east & Tonnang et al. (2014) \\
\hline \multicolumn{9}{|l|}{ Diptera: Psychodidae } \\
\hline $\begin{array}{l}\text { Lutzomyia antophora } \\
\text { and Lutzomyia } \\
\text { diabolica }\end{array}$ & Leishmaniasis & $\begin{array}{l}\text { North America } \\
\text { and Mexico }\end{array}$ & Yes & MaxEnt & $\begin{array}{l}2020,2050 \\
2080\end{array}$ & Expansion & North, northeast & González et al. (2010) \\
\hline $\begin{array}{l}\text { Lutzomyia longipalpis } \\
\text { and Lutzomyia } \\
\text { evansi }\end{array}$ & Leishmaniasis & Colombia & No & MaxEnt & $\begin{array}{l}2020,2050, \\
2080\end{array}$ & $\begin{array}{l}\text { Expansion or } \\
\text { contraction (at } \\
\text { different } \\
\text { scenarios) }\end{array}$ & North & González et al. (2014) \\
\hline $\begin{array}{l}\text { Lutzomyia spp. } \\
\text { (three species) }\end{array}$ & Leishmaniasis & South America & Yes & GARP & 2055 & Expansion & South, southeast & $\begin{array}{l}\text { Peterson and Shaw } \\
\text { (2003) }\end{array}$ \\
\hline $\begin{array}{l}\text { Phlebotominae } \\
\text { (28 species) }\end{array}$ & Leishmaniasis & $\begin{array}{l}\text { North and Central } \\
\text { Americas }\end{array}$ & No & GARP & $\begin{array}{l}\text { 2020, } 2050, \\
2080\end{array}$ & $\begin{array}{l}\text { Expansion in } 97 \% \text { of } \\
\text { species, } \\
\text { contraction in 3\% }\end{array}$ & $\begin{array}{l}\text { Northwest ( } 64 \% \text { of } \\
\text { species), northeast } \\
(35 \%) \text {, southeast } \\
(0,6 \%)\end{array}$ & Moo-Llanes et al. (2013) \\
\hline Phlebotomus papatasi & Leishmaniasis & Southeast Asia & No & $\begin{array}{l}\text { Discriminant } \\
\text { Analysis }\end{array}$ & Not given & Expansion & Not given & Cross and Hyams (1996) \\
\hline $\begin{array}{l}\text { Phlebotomus } \\
\text { perniciosus }\end{array}$ & Leishmaniasis & Bavaria, Germany & No & MaxEnt & 2040 & Expansion & Not given & Fischer et al. (2011b) \\
\hline
\end{tabular}


Table 1. (Cont.)

\begin{tabular}{|c|c|c|c|c|c|c|c|c|}
\hline Species & Main disease & Study area & $\begin{array}{l}\text { Full current } \\
\text { distribution } \\
\text { of species }\end{array}$ & Algorithm & $\begin{array}{l}\text { Year of } \\
\text { projections }\end{array}$ & $\begin{array}{l}\text { Difference of pro- } \\
\text { jected area }\end{array}$ & $\begin{array}{l}\text { General range shift } \\
\text { directions }\end{array}$ & Reference \\
\hline $\begin{array}{l}\text { Phlebotomus ariasi } \\
\text { and Phlebotomus } \\
\text { perniciosus }\end{array}$ & Leishmaniasis & Madrid, Spain & No & $\begin{array}{l}\text { GLM (negative } \\
\text { binomial) }\end{array}$ & $\begin{array}{l}2040,2070 \\
2100\end{array}$ & Expansion & Not given & Gálvez et al. (2011) \\
\hline $\begin{array}{l}\text { Phlebotomus spp. } \\
\text { (five species) }\end{array}$ & Leishmaniasis & $\begin{array}{l}\text { Southern } \\
\text { Germany }\end{array}$ & No & MaxEnt & 2040 & Expansion & Central, northwest & Haeberlein et al. (2013) \\
\hline $\begin{array}{l}\text { Phlebotomus spp. } \\
\text { (five species) }\end{array}$ & Leishmaniasis & Central Europe & No & MaxEnt & $\begin{array}{l}2040,2070, \\
2100\end{array}$ & Expansion & Mostly east & Fischer et al. (2011a) \\
\hline \multicolumn{9}{|l|}{ Diptera: } \\
\hline $\begin{array}{l}\text { Ceratopogonidae } \\
\text { Culicoides imicola }\end{array}$ & Bluetongue & Spain & No & $\begin{array}{l}\text { GLM (negative } \\
\text { binomial) }\end{array}$ & 2040 & Stability & Not given & Acevedo et al. (2010) \\
\hline Culicoides imicola & Bluetongue & Europe & No & GLM (logistic) & Not given & Expansion & North & Wittmann et al. (2001) \\
\hline Culicoides imicola & Bluetongue & Global & Yes & CLIMEX & 2030,2070 & $\begin{array}{l}\text { Expansion and } \\
\text { contraction }\end{array}$ & Mostly north & Guichard et al. (2014) \\
\hline \multicolumn{9}{|l|}{ Hemiptera: Reduviidae } \\
\hline $\begin{array}{l}\text { Triatoma gerstaeckeri } \\
\text { and Triatoma } \\
\text { sanguisuga }\end{array}$ & $\begin{array}{l}\text { Chagas } \\
\text { disease }\end{array}$ & Mexico and USA & Yes & MaxEnt & 2050 & Expansion & North, northeast & Garza et al. (2014) \\
\hline $\begin{array}{c}\text { Triatoma brasiliensis } \\
\text { species complex }\end{array}$ & $\begin{array}{l}\text { Chagas } \\
\text { disease }\end{array}$ & Northeast Brazil & Yes & MaxEnt, GARP & 2020,2050 & Stability & Not given & Costa et al. (2014) \\
\hline \multicolumn{9}{|l|}{ Acari: Ixodida } \\
\hline Ixodes ricinus & Lyme disease & Europe & No & GARP & 2050 & $\begin{array}{l}\text { Expansion and } \\
\text { contraction }\end{array}$ & North & $\begin{array}{l}\text { Boeckmann and Joyner } \\
\text { (2014) }\end{array}$ \\
\hline Ixodes ricinus & Lyme disease & Europe and Asia & Yes & MaxEnt & 2050,2080 & Expansion & North, east & Porretta et al. (2013) \\
\hline Ixodes scapularis & Lyme disease & $\begin{array}{l}\text { USA/Mexico } \\
\text { border }\end{array}$ & Yes & MaxEnt & 2050 & Expansion & Northeast & Feria-Arroyo et al. (2014) \\
\hline Ixodidae (six species) & Lyme disease & $\begin{array}{l}\text { Mediterranean } \\
\text { region }\end{array}$ & Yes & ENFA & Not given & Not given & Not given & $\begin{array}{l}\text { Estrada-Peña and } \\
\text { Venzal (2007) }\end{array}$ \\
\hline
\end{tabular}


Projections of its global distribution showed that most areas that are currently occupied should remain climatically favourable for its occurrence in 2030 and 2070, while new areas will become suitable for its range expansion, such as the Australian outback, the Arabian Peninsula, southern Iran and parts of North America (Khormi \& Kumar, 2014). Further projections for the near future indicate that suitable macroclimatic conditions for this vector should begin to expand between 2010 and 2039 (Capinha et al., 2014). In Brazil, models predict a contraction of its range in the northern and northeastern regions, accompanied by a probable expansion in the south by 2050 (Cardoso-Leite et al., 2014). Since $A$. aegypti is a vector with high adaptability to urban environments, its local distribution is also influenced by the occurrence of artificial breeding sites such as water tanks and swimming pools. In Australia, models based only on climatic variables failed to detect locations of its known occurrence and of human cases of dengue (Beebe et al., 2009). This inconsistency was attributed to human behaviour, as residents began to store water during a regional drought attributed to climate change (Beebe et al., 2009). The study pointed out, therefore, not only the local-scale limitations of ENM, but also the importance of implementing climate change adaptation measures that are compatible with disease control programs (Beebe et al., 2009). Despite not using the fullknown distribution of the vector in model training, predictions of future range contraction in Brazil (Cardoso-Leite et al., 2014) and of future inland expansion in Australia (Beebe et al., 2009) were similar to those predicted by models based on its global distribution (Capinha et al., 2014; Khormi \& Kumar, 2014).

In contrast to the highly anthropophilic A. aegypti, the Asian tiger mosquito $A$. albopictus prefers less disturbed environments and has predominantly zoophilic habits, participating in sylvatic transmission cycles of a number of arboviruses, such as chikungunya, yellow fever and dengue. Despite having relatively lower importance in human disease transmission than A. aegypti, the distribution of $A$. albopictus has been much studied because it is considered the most invasive mosquito species in the world (Benedict et al., 2007; Medley, 2010; Porretta et al., 2012). Its original distribution in Southeast Asia has expanded in recent decades to various countries in the Americas, Africa and Europe, mostly through cargo transportation (Reiter \& Sprenger, 1987; Tatem et al., 2006). In Europe, the species is currently established in the Mediterranean region, where local vector populations are already expanding (Roiz et al., 2011). Future projections of ENM point to an increase of climate suitability areas for A. albopictus in central and western parts of Europe by 2040, with eastern areas becoming suitable from 2070 onwards (Fischer et al., 2011c). Based on these projections, an assessment of the main cargo shipment routes concluded that certain areas of the continent, such as Rotterdam, Hamburg and Antwerp, have the dangerous combination of high incoming cargo from countries where A. albopictus occurs and high future climatic suitability for the vector (Thomas et al., 2014). In Australia, where there are currently no records of $A$. albopictus, niche models based on the global distribution of the vector show that the coastal region is climatically suitable for its establishment, with projections for the coming decades indicating expansion of this suitable area towards the interior of the country (Hill et al., 2014).

\section{Anopheles spp. (Diptera: Culicidae)}

The distributions of two malaria vectors in Sub-Saharan Africa, Anopheles gambiae and An. arabiensis, will also likely expand southwards and southeastwards, according to ENMs involving climate change scenarios (Peterson, 2009; Fuller et al., 2012; Tonnang et al., 2010, 2014). By adding mosquito survival rates to niche models, it was concluded that East African countries will have greater climatic suitability for these vectors in the coming decades than West African countries (Tonnang et al., 2014). Although the models predict local regions of both increase and decrease of climatic suitability for the vectors, $11-30 \%$ fewer people should be exposed to the vectors in the coming decades, as seen by overlaying model predictions and human distribution (Peterson, 2009). A more recent study pointed to a contraction of over half of the distribution area of An. arabiensis in West African countries (Drake $\&$ Beier, 2014). The overall contraction of the full range of the vector might erroneously suggest less exposure to vectorborne diseases with climate change. The association with human distribution demonstrates the caution needed when interpreting predictions of ENMs of vectors. Vector occurrence per se does not necessarily implies higher risk of disease transmission, and a closer look at other risk factors is needed.

\section{Lutzomyia spp. and Phlebotomus spp. (Diptera: Psychodidae)}

Leishmaniases are neglected tropical diseases widely distributed in 98 countries, with approximately $0.2-0.4$ million cases of visceral leishmaniasis and 0.7-1.2 million cases of cutaneous leishmaniasis occurring every year (Alvar et al., 2012). The vectors of leishmaniases, sand flies, are classified in two genera according to their distributions: Lutzomyia in the Americas and Phlebotomus in other continents. Areas climatically suitable for the South American vectors L. whitmani, L. intermedia and L. migonei should expand by the year 2050 (Peterson \& Shaw, 2003). Expansion areas are located in different regions of the continent, but their most evident direction is south, where $L$. whitmani will have larger suitability areas than the other two vectors (Peterson \& Shaw, 2003). In contrast, in Colombia, future projections from regional distribution models indicate reduction of the total predicted area of occurrence of L. longipalpis and L. evansi associated with changes in their altitudinal distribution (González et al., 2014). Unfortunately, failure to consider the full distribution of L. longipalpis might have produced biased predictions for Colombia (González et al., 2014), because the vector occupies a broad range of latitudes from Mexico to Argentina (World Health Organization, 2010).

The vectors $L$. anthophora and L. diabolica, currently distributed in Mexico and the USA, are projected to expand northwards (González et al., 2010). These projections were associated with predictions of the distributions of rodent hosts and human populations, and indicated that the expected number of people exposed to leishmaniases in North America will at least double by 2080 (González et al., 2010). Future northward expansions of suitable areas to leishmaniasis vectors are also expected for 27 of 28 species with current occurrence in Mexico, Guatemala, Belize, USA and Canada, the exception being L. vexator (Moo-Llanes et al., 2013). However, the predictions for species whose distributions include South America, such as L. longipalpis and L. shannoni, should be interpreted with caution because the models were only calibrated with data from Canada, USA, Mexico, Guatemala and Belize (Moo-Llanes et al., 2013).

Europe is currently on alert for the emergence of leishmaniasis and the expansion of its vectors, especially in the countries in central regions of the continent, predicted to become 
increasingly climatically similar to the Mediterranean region, where there are endemic areas of these diseases (Ready, 2008; Medlock et al., 2014). In a region of canine leishmaniasis in Spain, an increase in the abundance of $P$. ariasi in higher altitude areas was observed, pointing out to a possible migration of the vector to these areas in response to rising temperatures (Gálvez et al., 2010). Future projections predict expansions of the range and increase of local densities of both $P$. ariasi and P. perniciosus in the 21st century (Gálvez et al., 2011); however, models were restricted to Spain, which represents only part of the range of both species at the Mediterranean region (World Health Organization, 2010). In Germany, Austria and Switzerland, there are predicted areas of increased climate suitability for five species of Phlebotomus, but most are unlikely to be reached by the vectors by the end of this century due to their limited dispersal ability (Fischer et al., 2011a). This finding was reinforced by later field sampling in the region of Bavaria, southern Germany, where no sand flies were caught (Haeberlein et al., 2013). However, field studies show that several species of Phlebotomus from the Mediterranean region already have records of the expansion of their distributions towards central Europe (Maroli et al., 2008; Medlocket al., 2014).

\section{Culicoides spp. (Diptera: Ceratopogonidae)}

Bluetongue disease, a zoonotic infection transmitted by Culicoides spp. (biting midges) to various ruminants, has important economic impacts in temperate zones of Europe, Africa and the Americas. Some authors suggest that in the Mediterranean region there is evidence of northward expansion of C. imicola in recent decades (Purse et al., 2005), while others refute this (Conte et al., 2009). Future expansions of $C$. imicola in climate change scenarios are predicted for most of its occurrence areas in the northern hemisphere (mainly central and western Europe and the USA) and some contraction areas in Africa (Guichard et al., 2014). In Europe, their distribution is currently known in the Iberian Peninsula, with future climatically suitable areas predicted in the northwest direction, in climate change scenarios (Wittmann et al., 2001). In Spain, niche models of wild hosts of Bluetongue virus (deer and wild boar) were used as predictors of the occurrence of C. imicola, in addition to other environmental variables, showing that in the near future (2011-2040), its predicted distribution will not suffer many changes, but its abundance is expected to increase in currently occupied areas (Acevedo et al., 2010).

\section{Triatoma spp. (Hemiptera: Reduviidae)}

Chagas disease, also known as American trypanosomiasis, is transmitted by many species of kissing bugs from Triatominae subfamily. It was originally restricted to Latin America, but in past decades it has been detected in the USA, Canada, European and Asian countries, due mostly to human migration from endemic areas Schmunis \& Yadon, 2010). In Brazil, Triatoma brasiliensis, a species complex (Monteiro et al., 2004), is considered the main vector in the northeast region (Monteiro et al., 2004). Future projections of its distribution indicate few areas of both expansion and contraction, so its distribution may remain stable, at least until 2050 (Costa et al., 2014). In contrast, ENMs of two vectors of Chagas disease in the USA, T. gerstaeckeri and T. sanguisuga, predict northwards expansions of their distributions in response to climate change in 2050 (Garza et al., 2014).

\section{Ixodes spp. (Acari: Ixodida)}

Several species of Ixodes ticks are involved in the transmission of Lyme disease, which is the most prevalent vector-borne disease in the USA and Europe. It is vectored by I. scapularis and I. pacificus in North and Central America, and by I. persulcatus and I. ricinus in Europe and Asia (Lane et al., 1991).

The distribution of $I$. ricinus in Europe may nearly double by 2080 (Porretta et al., 2013). This predicted expansion includes areas north and east of its current range, reaching the northernmost regions of Eurasia, such as Sweden and Russia (Porretta et al., 2013). A model developed from a subset of its distribution records showed overall similar future predictions for Europe, with some local differences in the Iberian Peninsula and Scandinavia (Boeckmann \& Joyner, 2014). In the USA, models indicate current greater probability of occurrence of $I$. scapularis in the Gulf of Mexico, and future projections point to relative stability in its range by 2050 (Feria-Arroyo et al., 2014).

\section{Further considerations on niche models of disease vectors}

Vector occurrence data often present spatial bias towards endemic areas where disease surveillance programs are active. In addition, having presence and absence data that are required for some ENM algorithms is rarely the case when studying disease vectors. Most studies that used absence data based on field studies were restricted to regional and local scales, due to the inherent limitations of sampling effort (Eisen et al., 2006; Mushinzimana et al., 2006; Reiter \& Lapointe, 2007; Khatchikian et al., 2011; Cardo et al., 2014). Absence data can be replaced by pseudo-absences generated according to several criteria (Lobo \& Tognelli, 2011; Senay et al., 2013). Real absence data, however, can also be a source of bias in model outputs if they are not treated appropriately. After all, a species may be absent from a sampled region for various reasons besides the lack of environmental suitability, such as dispersion barriers, historical factors or biotic interactions (Lobo et al., 2010). In a modelling exercise to test different absence datasets of $C$. imicola, the removal of false absences improved all model outputs (Peters et al., 2011).

Most ENMs are correlative approaches based on abiotic factors; they do not consider species' dispersion (Guisan \& Zimmermann, 2000; Barve et al., 2011). Thus, knowledge of vector ecology becomes essential for interpretation of model outputs. Accessible localities in climatic suitability areas can be either hypothesised a priori (Barve et al., 2011; Carvalho et al., 2015) or mapped a posteriori for vectors with limited dispersal ability, such as sand flies (Fischer et al., 2011a). In contrast, ticks' dispersion is facilitated by their hosts' movements, favouring their range expansion in suitable areas (Porretta et al., 2013).

Health data are commonly grouped into administrative areas, such as municipalities, districts, states or countries. Automatically converting vector records from this format to point localities can generate positional errors, depending on the spatial resolution of the study, which might lead to wrong estimates of the species-environment relationship (Naimi et al., 2014). Even if the vector records for an ENM are aggregated into area units, they can be analysed using statistical methods, considering the spatial limitations of model predictions. This approach was applied in a GLM (logistic regression) of the environmental suitability of L. whitmani, cutaneous leishmaniasis vector in the state of Mato Grosso, Brazil, 
where both vector occurrence and environmental data were grouped at the municipal level (Zeilhofer et al., 2008).

To correctly interpret future ENM projections for disease vectors, it is important to remember that a vector's distribution represents only a fraction of the factors that determine human vector-borne diseases. Even if vectors, pathogens and hosts coexist in a location, the disease might not become endemic for several reasons. Human social factors play an important role in disease establishment, such as migration, urbanization, population immunity and effectiveness of health systems (Gage et al., 2008; Barcellos et al., 2009). For example, the incidence of malaria has declined since 1900, mainly due to effective control (Gething et al., 2010). However, in the areas of predicted expansion of distribution of malaria vectors in Africa there is more poverty and fewer resources to control the disease, which are important determinants of transmission risk (Peterson, 2009). International travel has contributed to increased numbers of imported cases of dengue in the USA and Europe (Gardner et al., 2012). Chagas disease, a chronic and silent infection currently treated as an emergent vector-borne disease in southern USA, may have been established in the region for over 70 years (Garcia et al., 2015), so the predicted expansion of vectors may increase transmission risk (Garza et al., 2014). Canine leishmaniasis transmission cycles, known to precede human outbreaks of the disease have been recorded in areas with no records of human cases, not only in European countries (Ready, 2010), but also in the USA and Canada (Duprey et al., 2006). These and other evidence points to the need for a multidisciplinary view of the impacts of climate change on vector-borne diseases.

\section{Conclusions}

Changes in the geographical distribution of vectors are expected with climate change, therefore impacting the spatial epidemiology of vector-borne diseases. Tropical regions of the world are currently occupied by many vector species, however future projections indicate poleward increases of suitable climates for their occurrence. These are the scenarios for Mediterranean vectors of several arboviruses, leishmaniasis, bluetongue disease and tick-borne infections, which are expected to find climatically suitable areas in central Europe for their expansions by the end of this century. In Sub-Saharan Africa, malaria vectors are expected to shift their distributions southward and eastward, losing climatic suitability in western countries in the process. Leishmaniasis vectors from tropical America are projected to expand their ranges both northwards and southwards in temperate zones, while inland Australia should increase in climatic suitability for mosquitoes.

The results discussed here are for the distribution of vectors only, which are a fraction of the determinants of the occurrence of these diseases. These likely vector expansions will only translate into increased risk of human disease if they are accompanied by hosts and parasites themselves. Human social factors and control efforts also play important roles in transmission risk. It is recommended that entomological monitoring activities are made, especially in the areas projected to become suitable for the occurrence of these vectors. Long-term monitoring studies can contribute substantially to the knowledge of the ecology of these species and how their distributions change in response to climate change.

Adoption of multiple ENM methods to study disease vector distributions is slow relative to the general ENM literature.
Another concern is the lack of consideration of the full-known current distribution of the target species on models that include future projections; about half of the reviewed studies had this issue, potentially leading to questionable predictions. An extra effort from authors is necessary in order to better understand the details of these methods so that models are produced with greater reliability and a clear description of their uncertainties. With this, these studies can support disease control policies more efficiently.

\section{Supplementary Material}

The supplementary material for this article can be found at https://doi.org/10.1017/S0007485316001097

\section{References}

Acevedo, P., Ruiz-Fons, F., Estrada, R., Márquez, A.L., Miranda, M.A., Gortázar, C., et al. (2010) A broad assessment of factors determining Culicoides imicola abundance: modelling the present and forecasting its future in climate change scenarios. PLOS ONE 5, e14236.

Alvar, J., Vélez, I.D., Bern, C., Herrero, M., Desjeux, P., Cano, J., Jannin, J., den Boer, M. \& the WHO Leishmaniasis Control Team (2012) Leishmaniasis worldwide and global estimates of its incidence. PLoS ONE 7(5), e35671.

Araújo, M. \& New, M. (2007) Ensemble forecasting of species distributions. Trends in Ecology and Evolution 22, 42-47.

Araújo, M.B. \& Peterson, A.T. (2012) Uses and misuses of bioclimatic envelope modelling. Ecology 93(7), 1527-1539.

Arboleda, S., Jaramillo-O, N. \& Peterson, A.T. (2009) Mapping environmental dimensions of dengue fever transmission risk in the Aburrá Valley, Colombia. International Journal of Environmental Research and Public Health 6, 3040-3055.

Arboleda, S., Jaramillo-O, N. \& Peterson, A.T. (2012) Spatial and temporal dynamics of Aedes aegypti larval sites in Bello, Colombia. Journal of Vector Ecology 37, 37-48.

Barcellos, C., Monteiro, A.M.V., Corvalán, C., Gurgel, H., Carvalho, M.S., Artaxo, P., Hacon, S. \& Ragoni, V. (2009) Mudanças climáticas e ambientais e as doenças infecciosas: cenários e incertezas para o Brasil. Epidemiologia e Serviços de Saúde 18, 285-304.

Barve, N., Barve, V., Jiménez-Valverde, A., Lira-Noriega, A., Maher, S.P., Peterson, A.T., Soberón, J. \& Villalobos, F. (2011) The crucial role of the accessible area in ecological niche modeling and species distribution modeling. Ecological Modelling 222, 1810-1819.

Beebe, N.W., Cooper, R.D., Mottram, P. \& Sweeney, A.W. (2009) Australia's dengue risk driven by human adaptation to climate change. PLoS Neglected Tropical Diseases 3, e429.

Benedict, M.Q., Levine, R.S., Hawley, W.A. \& Lounibos, L.P. (2007) Spread of the tiger: global risk of invasion by the mosquito Aedes albopictus. Vector-borne and Zoonotic Diseases 7, 76-85.

Boeckmann, M. \& Joyner, T.A. (2014) Old health risks in new places? An ecological niche model for $I$. ricinus tick distribution in Europe under a changing climate. Health \& Place 30, 70-77.

Booth, T.H., Nix, H.A., Busby, J.R. \& Hutchinson, M.F. (2014) BIOCLIM: the first species distribution modelling package, its early applications and relevance to most current MaxEnt studies. Diversity and Distributions 20, 1-9.

Breiman, L. (2001) Random forests. Machine Learning 45, 15-32. 
Brooks, D.R. \& Hoberg, E.P. (2007) How will global climate change affect parasite-host assemblages? Trends in Parasitology 23(12), 571-574.

Buisson, L., Thuiller, W., Casajus, N., Lek, S. \& Grenouillette, G. (2009) Uncertainty in ensemble forecasting of species distribution. Global Change Biology 16, 1145-1157.

Capinha, C., Rocha, J. \& Sousa, C.A. (2014) Macroclimate determines the global range limit of Aedes aegypti. EcoHealth 11, 420-428.

Cardo, M.V., Vezzani, D., Rubio, A. \& Carbajo, A.E. (2014) Integrating demographic and meteorological data in urban ecology: a case study of container-breeding mosquitoes in temperate Argentina. Area 46(1), 18-26.

Cardoso-Leite, R., Vilarinho, A.C., Novaes, M.C., Tonetto, A.F., Vilardi, A.C. \& Guillermo-Ferreira, R. (2014) Recent and future environmental suitability to dengue fever in Brazil using species distribution model. Transactions of the Royal Society of Tropical Medicine and Hygiene 108, 99-104.

Carpenter, G., Gillison, A.N. \& Winter, J. (1993) DOMAIN: a flexible modeling procedure for mapping potential distributions of plants and animals. Biodiversity and Conservation 2, 667-680.

Carvalho, B.M., Rangel, E.F., Ready, P.D. \& Vale, M.M. (2015) Ecological niche modelling predicts southward expansion of Lutzomyia (Nyssomyia) flaviscutellata (Diptera: Psychodidae: Phlebotominae), vector of Leishmania (Leishmania) amazonensis in South America, under climate change. PLOS ONE 10 (11), e0143282.

Chen, I.-C., Hill, J.K., Ohlemüller, R., Roy, D.B. \& Thomas, C. D. (2011) Rapid range shifts of species associated with high levels of climate warming. Science 333(6045), 10241026.

Conte, A., Gilbert, M. \& Goffredo, M. (2009) Eight years of entomological surveillance in Italy show no evidence of Culicoides imicola geographical range expansion. Journal of Applied Ecology 46, 1332-1339.

Costa, J., Dornak, L.L., Almeida, C.E. \& Peterson, A.T. (2014) Distributional potential of the Triatoma brasiliensis species complex at present and under scenarios of future climate conditions. Parasites $\mathcal{E}$ Vectors 7, 238.

Cross, E.R. \& Hyams, K.C. (1996) The potential effect of global warming on the geographic and seasonal distribution of Phlebotomus papatasi in Southwest Asia. Environmental Heath Perspectives 104(7), 724-727.

Daszak, P., Zambrana-Torrelio, C., Bogich, T.L., Fernandez, M., Epstein, J.H., Murray, K.A. \& Hamilton, H. (2013) Interdisciplinary approaches to understanding disease emergence: the past, present and future drivers of Nipah virus emergence. Proceedings of the National Academy of Sciences of the United States of America 110(Suppl. 1), 36813688.

Diniz-Filho, J.A.F., Bini, L.M., Rangel, T.F., Loyola, R.D., Hof, C., Nogués-Bravo, D. \& Araújo, M. (2009) Partitioning and mapping uncertainties in ensembles of forecasts of species under climate change. Ecography 32, 897-906.

Dormann, C.F., Purschke, O., Márquez, J.R.G., Lautenbach, S. \& Schröder, B. (2008) Components of uncertainty in species distribution analysis: a case study of the great grey shrike. Ecology 89(12), 3371-3386.

Dormann, C.F., Schymanski, S.J., Cabral, J., Chuine, I., Graham, C., Hartig, F., Kearney, M., Morin, X., Römermann, C., Schröder, B. \& Singer, A., (2012) Correlation and process in species distribution models: bridging a dichotomy. Journal of Biogeography 39, 2119-2131.
Drake, J.M. \& Beier, J.C. (2014) Ecological niche and potential distribution of Anopheles arabiensis in Africa in 2050. Malaria Journal 13, 213.

Duprey, Z.H., Steurer, F.J., Rooney, J.A., Kirchhoff, L.V., Jackson, J.E., Rowton, E.D. \& Schantz, P.M. (2006) Canine visceral leishmaniasis, United States and Canada, 2000-2003. Emerging Infectious Diseases 12(3), 440-446.

Eisen, L., Eisen, R.J. \& Lane, R.S. (2006) Geographical distribution patterns and habitat suitability models for presence of host-seeking Ixodid ticks in dense woodlands of Mendocino County, California. Journal of Medical Entomology 43(2), 415427.

Eisen, L., Monaghan, A.J., Lozano-Fuentes, S., Steinhoff, D.F., Hayden, M.H. \& Bieringer, P.E. (2014) The impact of temperature on the bionomics of Aedes (Stegomyia) aegypti, with special reference to the cool geographic range margins. Journal of Medical Entomology 51(3), 496-516.

Elith, J. \& Graham, C. (2009) Do they? How do they? WHY do they differ? On finding reasons for differing performances of species distribution models. Ecography 32, 66-67.

Elith, J. \& Leathwick, J.R. (2009) Species distribution models: ecological explanation and prediction across space and time. Annual Review of Ecology, Evolution and Systematics 40, 677697.

Elith, J., Graham, C.H., Anderson, R.P., Dudík, M., Ferrier, S., Guisan, A., Hijmans, R.H., Huettmann, F., Leathwick, J.R., Lehmann, A., Li, J., Lohmann, L.G., Loislelle, B.A., Manion, G., Moritz, C., Nakamura, M., Nakazawa, Y., Overton, J. McC., Townsend Peterson, A., Phillips, S.J., Richardson, K., Scachetti-Pereira, R., Schapire, R.E., Soberón, J., Williams, S., Wisz, M.S. \& Zimmermann, N.E. (2006) Novel methods improve prediction of species' distributions from occurrence data. Ecography 29, 129-151.

Elith, J., Leathwick, J.R. \& Hastie, T. (2008) A working guide to boosted regression trees. Journal of Animal Ecology 77, 802881.

Estrada-Peña, A. \& Venzal, J.M. (2007) Climate niches of tick species in the Mediterranean region: modeling of occurrence data, distributional constraints, and impact of climate change. Journal of Medical Entomology 44(6), 1130-1138.

Falagas, M.E., Pitsouni, E.I., Malietzis, G.A. \& Pappas, G. (2008) Comparison of pubmed, Scopus, Web of Science, and Google Scholar: strengths and weakness. The FASEB Journal 22, 338342.

Feria-Arroyo, T.P., Castro-Arellano, I., Gordillo-Perez, G., Cavazos, A.L., Vargas-Sandovál, M., Grover, A., Torres, J., Medina, R.F., Pérez de León, A.A. \& Esteve-Gassent, M.D. (2014) Implications of climate change on the distribution of the tick vector Ixodes scapularis and risk for Lyme disease in the Texas-Mexico transboundary region. Parasites $\mathcal{E}$ Vectors 7 , 199.

Fischer, D., Moeller, P., Thomas, S.M., Naucke, T.J. \& Beierkuhnlein, C. (2011a) Combining climatic projections and dispersal ability: a method for estimating the responses of sand fly vector species to climate change. PLoS Neglected Tropical Diseases 5(11), e1407.

Fischer, D., Thomas, S.M. \&, Beierkuhnlein, C. (2011b) Modelling climatic suitability and dispersal for disease vectors: the example of a phlebotomine sandfly in Europe. Procedia Environmental Sciences 7, 164-169.

Fischer, D., Thomas, S.M., Niemitz, F., Reineking, B. \& Beierkuhnlein, C. (2011c) Projection of climatic suitability for Aedes albopictus Skuse (Culicidae) in Europe under climate change conditions. Global and Planetary Change 78, 54-64. 
Fischer, D., Thomas, S.M., Neteler, M., Tjaden, N.B. \& Beierkuhnlein, C. (2014) Climatic suitability of Aedes albopictus in Europe referring to climate change projections: comparison of mechanistic and correlative niche modelling approaches. Euro Surveillance 19(6), 20696.

Fitzpatrick, M. C. \& Hargrove, W.W. (2009) The projection of species distribution models and the problem of non-analog climate. Biodiversity and Conservation 18, 2255-2261.

Foley, D.H., Klein, T.A., Kim, H.C., Sames, W.J., Wilkerson, R.C. \& Rueda, L.M. (2009) Geographic distribution and ecology of potential malaria vectors in the Republic of Korea. Journal of Medical Entomology 46(3), 680-692.

Foley, D.H., Klein, T.A., Kim, H.C., Brown, T., Wilkerson, R.C. \& Rueda, L.M. (2010) Validation of ecological niche models for potential malaria vectors in the republic of Korea. Journal of the American Mosquito Control Association 26(2), 210-213.

Franklin, J. (2010) Mapping Species Distributions. Spatial Inference and Prediction. Cambridge, Cambridge University Press.

Fuller, D.O., Parenti, M.S., Hassan, A.L. \& Beier, J.C. (2012) Linking land cover and species distribution models to project potential ranges of malaria vectors: an example using Anopheles arabiensis in Sudan and Upper Egypt. Malaria Journal 11, 264.

Gage, K.L., Burkot, T.R., Eisen, R.J. \& Hayes, E.B. (2008) Climate and vectorborne diseases. American Journal of Preventive Medicine 35(5), 436-450.

Gálvez, R., Descalzo, M.A., Miró, G., Jiménez, M.I., Martín, O., Sandos-Brandao, F., Guerrero, I., Cubero, E. \& Molina, R. (2010) Seasonal trends and spatial relations between environmental/meteorological factors and leishmaniosis sand fly vector abundances in Central Spain. Acta Tropica 115, 95-102.

Gálvez, R., Descalzo, M.A., Guerrero, I., Miró, G. \& Molina, R. (2011) Mapping the current distribution and predicted spread of the leishmaniosis sand fly vector in the Madrid region (Spain) based on environmental variables and expected climate change. Vector-Borne and Zoonotic Diseases 11 (7), 799-806.

Garcia, M.N., Woc-Colburn, L., Aguilar, D., Hotez, P.J. \& Murray, K.O. (2015) Historical perspectives on the epidemiology of human Chagas disease in Texas and recommendations for enhanced understanding of clinical Chagas disease in the southern United States. PLoS Neglected Tropical Diseases 9(11), e0003981.

Gardner, L.M., Fajardo, D., Waller, S.T., Wang, O. \& Sarkar, S.A. (2012) A predictive spatial model to quantify the risk of air-travel-associated dengue importation into the United States and Europe. Journal of Tropical Medicine 2012, 103679.

Garza, M., Arroyo, T.P.F., Casillas, E.A., Sanchez-Cordero, V., Rivaldi, C.-L. \& Sarkar, S. (2014) Projected future distributions of vectors of Trypanosoma cruzi in North America under climate change scenarios. PLoS Neglected Tropical Diseases $\mathbf{8}$ (5), e2818.

Gavel, Y. \& Iselid, L. (2008) Web of Science and Scopus: a journal title overlap study. Online Information Review 32, 475-484.

Gething, P.W., Smith, D.L., Patil, A.P., Tatem, A.J., Snow, R.W. \& Hay, S.I. (2010) Climate change and the global malaria recession. Nature 465, 342-346.

González, C., Wang, O., Strutz, S.E., González-Salazar, C., Sánchez-Cordero, V. \& Sarkar, S. (2010) Climate change and risk of leishmaniasis in North America: predictions from ecological niche models of vector and reservoir species. PLoS Neglected Tropical Diseases 4(1), e585.

González, C., Paz, A. \& Ferro, C. (2014) Predicted altitudinal shifts and reduced spatial distribution of Leishmania infantum vector species under climate change scenarios in Colombia. Acta Tropica 129, 83-90.

Guichard, S., Guis, H., Tran, A., Garros, C., Balenghien, T. \& Kriticos, D.J. (2014) Worldwide niche and future potential distribution of Culicoides imicola, a major vector of Bluetongue and African horse sickness viruses. PLOS ONE 9(11), e112491.

Guillera-Arroita, G., Lahoz-Monfort, J.J., Elith, J., Gordon, A., Kujala, H., Lentini, P.E., McCarthy, M.A., Tingles, R. \& Wintle, B.A. (2015) Is my species distribution model fit for purpose? Matching data and models to applications. Global Ecology and Biogeography 24, 276-292.

Guisan, A. \& Thuiller, W. (2005) Predicting species distribution: offering more than simple habitat models. Ecology Letters $\mathbf{8}$, 993-1009.

Guisan, A. \& Zimmermann, N.E. (2000) Predictive habitat distribution models in ecology. Ecological Modelling 135, 147-186.

Guisan, A., Edwards, T.C. \& Hastie, T. (2002) Generalized linear and generalized additive models in studies of species distributions: setting the scene. Ecological Modelling 157, 89-100.

Haeberlein, S., Fischer, D., Thomas, S.M., Schleicher, U., Beierkuhnlein, C. \& Bogdan, C. (2013) First assessment for the presence of Phlebotomine vectors in Bavaria, Southern Germany, by combined distribution modelling and field surveys. PLOS ONE 8(11), e81088.

Harrison, J.F. \& Roberts, S.P. (2000) Flight respiration and energetics. Annual Review of Physiology 62, 179-205.

Hickling, R., Roy, D.B., Hill, J.K., Fox, R. \& Thomas, C.D. (2006) The distributions of a wide range of taxonomic groups are expanding polewards. Global Change Biology 12, 450-455.

Hill, M.P., Axford, J.K. \& Hoffmann, A.A. (2014) Predicting the spread of Aedes albopictus in Australia under current and future climates: multiple approaches and datasets to incorporate potential evolutionary divergence. Austral ecology 39, 469-478.

Hirzel, A.H., Hausser, J., Chessel, D. \& Perrin, N. (2002) Ecological-niche factor analysis: how to compute habitatsuitability maps without absence data? Ecology 83(7), 20272036.

Hlavacova, J., Votypka, J. \& Volf, P. (2013) The effect of temperature on Leishmania (Kinetoplastida: Trypanosomatidae) development in sand flies. Journal of Medical Entomology 50(5), 955-958.

IPCC. (2014) Core Writing Team, in Pachauri, R.K. and Meyer, L.A. (eds). Climate Change 2014: Synthesis Report. Contribution of Working Groups I, II and III to the Fifth Assessment Report of the Intergovernmental Panel on Climate Change. Geneva, IPCC. 31 p.

Kearney, M. \& Porter, W. (2009) Mechanistic niche modelling: combining physiological and spatial data to predict species' ranges. Ecology Letters 12, 334-350.

Khatchikian, C., Sangermano, F., Kendell, D. \& Livdahl, T. (2011) Evaluation of species distribution model algorithms for fine-scale container-breeding mosquito risk prediction. Medical and Veterinary Entomology 25, 268-275.

Khormi, H.M. \& Kumar, L. (2014) Climate change and the potential global distribution of Aedes aegypti: spatial modelling using geographical information system and CLIMEX. Geospatial Health 8(2), 405-415.

Komar, N. (2003) West Nile virus: epidemiology and ecology in North America. Advances in Virus Research 61, 185-234.

Kovats, R.S., Campbell-Lendrum, D.H., Mcmichael, A.J., Woodward, A. \& Cox, J.H. (2001) Early effects of climate change: do they include changes in vector-borne diseases? Philosophical Transactions of the Royal Society London B 356, 1057-1068. 
Lane, R.S., Piesman, J. \& Burgdorfer, W. (1991) Lyme borreliosis: relation of its causative agent to its vectors and hosts in North America and Europe. Annual Review of Entomology 36(1), 587609.

Larson, S.R., Degroote, J.P., Bartholomay, L.C. \& Sugumaran, R. (2010) Ecological niche modeling of potential West Nile virus vector mosquito species in Iowa. Journal of Insect Science 10, 110.

Li, X. \& Wang, Y. (2013) Applying various algorithms for species distribution modelling. Integrative Zoology 8, 124-135.

Lobo, J.M. \& Tognelli, M.F. (2011) Exploring the effects of quantity and location of pseudo-absences and sampling biases on the performance of distribution models with limited point occurrence data. Journal for Nature Conservation 19, $1-7$.

Lobo, J.M., Jiménez-Valverde, A. \& Hortal, J. (2010) The uncertain nature of absences and their importance in species distribution modelling. Ecography 33, 103-114.

Marmion, M., Parviainen, M., Luoto, M., Heikkinen, R.K. \& Thuiller, W. (2009) Evaluation of consensus methods in predictive species distribution modelling. Diversity and Distributions 15, 59-69.

Maroli, M., Rossi, L., Baldelli, R., Capelli, G., Ferroglio, E., Genchi, C., Gramicia, M., Mortarino, M., Pietrobelli, M. \& Gradoni, L. (2008) The northward spread of leishmaniasis in Italy: evidence from retrospective and ongoing studies on the canine reservoir and phlebotomine vectors. Tropical Medicine and International Health 13(2), 256-264.

Medley, K.A. (2010) Niche shifts during the global invasion of the Asian tiger mosquito, Aedes albopictus Skuse (Culicidae), revealed by reciprocal distribution models. Global Ecology and Biogeography 19, 122-133.

Medlock, J.M., Hansford, K.M., Van Bortel, W., Zeller, H. \& Alten, B. (2014) A summary of the evidence for the change in European distribution of phlebotomine sand flies (Diptera: Psychodidae) of public health importance. Journal of Vector Ecology 39(1), 72-77.

Mills, J.N., Gage, K.L., Khan, A.S. (2010) Potential influence of climate change on vector-borne and zoonotic diseases: a review and proposed research plan. Environmental Health Perspectives 118(11), 1507-1514.

Monteiro, F.A., Donnelly, M.J., Beard, C.B. \& Costa, J. (2004) Nested clade and phylogeographic analyses of the Chagas disease vector Triatoma brasiliensis in Northeast Brazil. Molecular Phylogenetics and Evolution 32(1), 46-56.

Moo-Llanes, D., Ibarra-Cerdeña, C.N., Rebollar-Téllez, E.A., Ibáñez-Bernal, S., González, C. \& Ramsey, J.M. (2013) Current and future niche of North and Central American sand flies (Diptera: Psychodidae) in climate change scenarios. PLoS Neglected Tropical Diseases 7(9), e2421.

Mushinzimana, E., Munga, S., Minakawa, N., LI, L., Feng, C., Bian, L., Kitron, U., Schmidt, C., Beck, L., Zhou, G., Githeko, A.K. \& Yan, G., (2006) Landscape determinants and remote sensing of anopheline mosquito larval habitats in the western Kenya highlands. Malaria Journal 5, 13.

Naimi, B., Hamm, N.A.S., Groen, T.A., Skidmore, A.K. \& Toxopeus, A.G. (2014) Where is positional uncertainty a problem for species distribution modelling? Ecography 37, 191-203.

Nieto, P., Malone, J.B. \& Bavia, M.E. (2006) Ecological niche modeling for visceral leishmaniasis in the state of Bahia, Brazil, using genetic algorithm for rule-set prediction and growing degree day-water budget analysis. Geospatial Health 1, 115-126.
Owens, H.L., Campbell, L.P., Dornak, L., Saupe, E.E., Barve, N., Soberón, J., Ingenloff, K., Lira-Noriega, A., Hensz, C.M., Myers, C.E. \& Towsend Peterson, A. (2013) Constraints on interpretation of ecological niche models by limited environmental ranges on calibration areas. Ecological Modelling 263, 10-18.

Paaijmans, K.P., Heinig, R.L., Seliga, R.A., Blanford, J.I., Blanford, S., Murdock, C.C. \& Thomas, M.B. (2013) Temperature variation makes ectotherms more sensitive to climate change. Global Change Biology 19(8), 2373-2380.

Parham, P.E., Waldock, J., Christophides, G.K., Hemming, D., Agusto, F., Evans, K.J., Feffermann, N., Gaff, H., Gumel, A., LaDeau, S., Lenhart, S., Mickens, R.E., Naumova, E.N., Ostfeld, R.S., Ready, P.D., Thomas, M.B., VelascoHernandez, J. \& Michael, E. (2015) Climate, environmental and socio-economic change: weighing up the balance in vector-borne disease transmission. Philosophical Transactions of the Royal Society B 370, 20130551.

Pearson, R.G. \& Dawson, T.P. (2003) Predicting the impacts of climate change on the distribution of species: are bioclimatic envelope models useful? Global Ecology \& Biogeography 12, 361-371.

Pearson, R.G., Thuiller, W., Araújo, M.B., Martinez-Meyer, E., Brotons, L., Mcclean, C., Miles, L., Segurado, P., Dawson, T. P. \& Lees, D.C. (2006) Model-based uncertainty in species range prediction. Journal of Biogeography 33, 1704-1711.

Peters, J., De Baets, B., Van Doninck, J., Calvete, C., Lucientes, J., De Clercq, E.M., Ducheyne, E. \& Verhoest, N.E.C. (2011) Absence reductions in entomological surveillance data to improve niche-based distribution models for Culicoides imicola. Preventive Veterinay Medicine 100, 15-28.

Peterson, A.T. (2009) Shifting suitability for malaria vectors across Africa with warming climates. BMC Infectious Diseases 9, 59.

Peterson, A.T. \& Shaw, J.J. (2003) Lutzomyia vectors for cutaneous leishmaniasis in Southern Brazil: ecological niche models, predicted geographic distributions, and climate change effects. International Journal for Parasitology 33, 919-931.

Peterson, A.T., Soberón, J., Pearson, R.G., Anderson, R.P., Martínez-Meyer, E., Nakamura, M. \& Araújo, M.B. (2011) Ecological Niches and Geographic Distributions. Monographs in Population Biology 49. New Jersey, Princeton University Press.

Phillips, S.J., Anderson, R.P. \& Schapire, R.E. (2006) Maximum entropy modeling of species geographic distributions. Ecological Modelling 190, 231-259.

Porretta, D., Mastrantonio, V., Bellini, R., Somboon, P. \& Urbanelli, S. (2012) Glacial history of a modern invader: phylogeography and species distribution modelling of the Asian tiger mosquito Aedes albopictus. PLoS ONE 7(9), e44515.

Porretta, D., Mastrantonio, V., Amendolia, S., Gaiarsa, S., Epis, S., Genchi, C., Bandi, C., Otranto, D. \& Urbanelli, S., (2013) Effects of global changes on the climatic niche of the tick Ixodes ricinus inferred by species distribution modelling. Parasites \& Vectors 6, 271.

Purse, B.V., Mellor, P.S., Rogers, D.J., Samuel, A.R., Mertens, P.P.C. \& Baylis, M. (2005) Climate change and the recent emergence of bluetongue in Europe. Nature Reviews Microbiology 3, 171-181.

Qiao, H., Soberón, J. \& Peterson, A.T. (2015) No silver bullets in correlative ecological niche modelling: insights from testing among many potential algorithms for niche estimation. Methods in Ecology and Evolution 6(10), 1126-1136. 
Ready, P. (2008) Leishmaniasis emergence and climate change. Revue Scientifique et Technique de L'Office International des Epizooties 27(2), 399-412.

Ready, P.D. (2010) Leishmaniasis emergence in Europe. Euro Surveillance 15(10), 19505.

Ready, P.D. (2013) Biology of phlebotomine sand flies as vectors of disease agents. Annual Reviews in Entomology 58, 227-250.

Reiter, M.E. \& Lapointe, D.A. (2007) Landscape factors influencing the spatial distribution and abundance of mosquito vector Culex quinquefasciatus (Diptera: Culicidae) in a mixed residential-agricultural community in Hawai'i. Journal of Medical Entomology 44(5), 861-868.

Reiter, P. \& Sprenger, D. (1987) The used tire trade: a mechanism for the worldwide dispersal of container breeding mosquitoes. Journal of the American Mosquito Control Association 3, 494-501.

Rogers, D.J. \& Randolph, S.E. (2006) Climate change and vector-borne diseases. Advances in Parasitology 62, 345-381.

Rogers, D.J., Hay, S.I. \& Packer, M.J. (1996) Predicting the distribution of tsetse flies in West Africa using temporal Fourier processed meteorological satellite data. Annals of Tropical Medicine and Parasitology 90(3), 225-241.

Roiz, D., Neteler, M., Castellani, C., Arnoldi, D. \& Rizzoli, A. (2011) Climatic factors driving invasion of the tiger mosquito (Aedes albopictus) into new areas of Trentino, northern Italy. PLOS ONE 6(4), e14800.

Rosenthal, J. (2009) Climate change and the geographical distribution of infectious diseases. Ecohealth 6(4), 189-495.

Schäfer, M.L. \& Lundström, J.O. (2009) The present distribution and predicted geographic expansion of the floodwater mosquito Aedes sticticus in Sweden. Journal of Vector Ecology 34(1), 141-147.

Schmunis, G.A., \& Yadon, Z.E. (2010) Chagas disease: a Latin American health problem becoming a world health problem. Acta tropica 115(1), 14-21.

Senay, S.D., Worner, S.P. \& Ikeda, T. (2013) Novel three-step pseudo-absence selection technique for improved species distribution modelling. PLoS ONE 8(8), e71218.

Stange, E.E. \& Ayres, M.P. (2010) Climate change impacts: insects. In Encyclopedia of Life Sciences (ELS). Chichester, John Wiley \& Sons.

Stockwell, D. (1999) The GARP modelling system: problems and solutions to automated spatial prediction. International Journal of Geographical Information 13(2), 143-158.

Sutherst, R.W. \& Maywald, G.F. (1985) A computerised system for matching climates in ecology. Agriculture, Ecosystems $\mathcal{E}$ Environment 13, 281-299.
Tatem, A.J., Hay, S.I. \& Rogers, D. (2006) Global traffic and disease vector dispersal. Proceedings of the National Academy of Sciences of the United States of America 103(16), 6242-6247.

Thomas, S.M., Tjaden, N.B., Van Den Bos, S. \& Beierkuhnlein, C. (2014) Implementing cargo movement into climate based risk assessment of vector-borne diseases. International Journal of Environmental Research and Public Health 11, 3360 3374.

Tonnang, H.E.Z., Kangalawe, R.Y.M. \& Yanda, P.Z. (2010) Predicting and mapping malaria under climate change scenarios: the potential redistribution of malaria vectors in Africa. Malaria Journal 9, 111.

Tonnang, H.E.Z., Tchouassi, D.P., Juarez, H.S., Igweta, L.K. \& Djouaka, R.F. (2014) Zoom in at African country level: potential climate induced changes in areas of suitability for survival of malaria vectors. International Journal of Health Geographics 13, 12.

World Health Organization (2010) Control of the leishmaniases: report of a meeting of the WHO expert committee on the control of leishmaniases, Geneva, 22-26 March 2010. WHO Technic Report Series, no. 949. Geneva, WHO Press.

Williams, R.A.J., Fasina, F.O. \& Peterson, A.T. (2008) Predictable ecology and geography of avian influenza (H5N1) transmission in Nigeria and West Africa. Transactions of the Royal Society of Tropical Medicine and Hygiene 102, 471-479.

Wittmann, E.J., Mellor, P.S. \& Baylis, M. (2001) Using climate data to map the potential distribution of Culicoides imicola (Diptera: Ceratopogonidae) in Europe. Revue Scientifique et Technique de L'Office International des Epizooties 20(3), 731-740.

Woodward, A., Smith, K.R., Campbell-Lendrum, D., Chadee, D. D., Honda, Y., Liu, Q., Olwoch, J., Revich, B., Sauerborn, R., Chafe, Z., Confalonieri, U. \& Haines, A. (2014) Climate change and health: on the latest IPCC report. The Lancet 383, 1185-1189.

Yé, Y., Louis, V.R., Simboro, S. \& Sauerborn, R. (2007) Effect of meteorological factors on clinical malaria risk among children: an assessment using village-based meteorological stations and community-based parasitological survey. BMC Public Health 7, 101.

Zeilhofer, P., Kummer, O.P., dos Santos, E.S., Ribeiro, A.L.M. \& Missawa, N.A. (2008) Spatial modelling of Lutzomyia (Nyssomyia) whitmani s.l. (Antunes \& Coutinho, 1939) (Diptera: Psychodidae: Phlebotominae) habitat suitability in the state of Mato Grosso, Brazil. Memórias do Instituto Oswaldo Cruz 103(7), 653-660. 